\title{
The Institutional Foundations of Democratic Cooperation in Costa Rica*
}

\author{
FABRICE EDOUARD LEHOUCQ
}

Abstract. Costa Rica's long-term standing as one of the few countries in Latin America with a stable democracy has prompted many to view its polity as an inevitable outcome of a racially homogeneous and relatively egalitarian society. Without ignoring the importance of sociological factors, this article contends that institutional arrangements played an equally important - if not more central role in the development of a stable democratic regime in this country. The structure of Costa Rican presidentialism encouraged incumbents to maintain control of the state while it, as a consequence, incited the opposition to rebel against central state authorities. Political competition became more peaceful as parties that failed to hold or to capture the presidency were nevertheless compensated by being allowed to occupy legislative seats.

Along with Chile and Uruguay, Costa Rica is a country where a nineteenth-century republican system was gradually transformed into a fully-fledged democracy. At different times during the nineteenth century, politicians in these countries began to eschew the use of violence to obtain control of the state. As they began to compete for public offices in regularly scheduled elections, they also negotiated agreements to expand the franchise and to curtail the practice of electoral fraud. Why did politicians in Costa Rica decide to respect the results of the ballot box? Why did they create stable democratic institutions?

Prevailing interpretations contend that the democratisation of the Costa Rican polity was inevitable. Some focus on the alleged democratic nature of Costa Rican political culture. Others argue that democracy was a product of a relatively egalitarian class structure in a population which was homogeneous and/or had a reasonable level of economic de-

* Much of the research upon which this article is based was made possible by an International Doctoral Research Fellowship furnished by the Social Science Research Council and the American Council of Learned Societies. I acknowledge the research assistance supplied by Vilma Pella, Rafael Jimenez and Sara Soto Orozco. I also thank Barry Ames, John Carey, Clark Gibson, Iván Molina Jimenez, Matthew Shugart, Arturo Valenzuela and Bruce M. Wilson for comments on earlier versions of this paper.

Fabrice Edouard Lehoucq is Assistant Professor of Government and Public Affairs,

Christopher Newport University, Newport News, Virginia

L. Lat. Amer. Stud. 28, 329-355 Copyright (C) 1996 Cambridge University Press 
velopment. All assume that the characteristics of Costa Rican society are the causes of political behaviour.

The validity of these explanations, however, is premised upon an inaccurate portrait of Costa Rican politics. Until well into the twentieth century, most presidents in Costa Rica had come to power through the force of arms or in elections marred by fraud and violence. Only eight out of the forty-eight presidents between 1824 and 1949, for example, came to power in competitive and fair elections. ${ }^{1}$ Even without being wracked by the ethnic and class cleavages experienced by so many societies, the very struggle to retain or to gain control of the state has generated the discord responsible for the outbreak of violence and fraud and even regime breakdown in Costa Rica.

This article argues that a society with a great deal of underlying consensus does not inevitably lead to the consolidation of a democratic regime. Without ignoring the importance of economic and sociological factors, I contend that constitutional arrangements and the nature of political institutions play an equally important - if not more central - role in the development of stable democratic regimes. Like many other institutionalists, my article focuses upon how strategic behaviour is shaped by institutions and how such behaviour in turn can transform existing political arrangements. ${ }^{2}$ And, like other analysts of presidential forms of government, I show how the structure of executive-legislative relations can exert a powerful impact upon political stability. ${ }^{3}$

1 James L. Busey, ' The Presidents of Costa Rica', The Americas, vol. 18, no. 1 (1961).

2 I am echoing the claims made by Arturo Valenzuela and John Peeler that the choices made by politicians shaped the democratic trajectories of countries like Chile and Costa Rica. I build upon this observation by showing how the behaviour of politicians was decisively influenced by the incentives generated by prevailing institutional arrangements. See John A. Peeler, Latin American Democracies: Colombia, Costa Rica and Venezuela (Chapel Hill, 1984) and especially Arturo Valenzuela and J. Samuel Valenzuela, ' Los orígenes de la democracia : reflexiones teóricas sobre el caro de Chile', Estudios Públicos (Santiago de Chile), No. 13 (spring 1983). Works within the genre of the new institutionalisim include: Robert H. Bates, Beyond the Miracle of the Market: The Political Economy of Agrarian Development in Kenya (Cambridge, 1989); Gary W. Cox, The Efficient Secret: The Cabinet and the Development of Political Parties in Victorian England (Cambridge, 1987) and Charles Stewart, III, Budget Reform Politics: The Design of the Appropriations Process in the House of Representatives (Cambridge, 1989). The most recent theoretical discussions of the new institutionalism are Jack Knight, Institutions and Social Conflict (Cambridge, 1992) and George Tsebelis, Nested Games: Rational Choice in Comparative Politics (Berkeley, 199o).

3

Though, I must add, I do not examine how electoral laws and party systems generate dividied governments. Here, I focus upon the consequences of an omnipotent presidency on democratic stability. The most thorough discussion of the prior set of issues are : Mark P. Jones, Electoral Laws and the Survival of Presidential Democracies (Notre Dame, 1995); Juan Linz and Arturo Valenzuela (eds.), The Failure of Presidential Democracy (Baltimore, 1994) and Matthew Soberg Shugart and John M. Carey, Presidents and Assemblies: Constitutional Design and Electoral Dynamics (Cambridge, 199z). 
My principal aims are, first, to offer an institutions-based interpretation of the development of democracy in Costa Rica. I show how the gradual development of respect for the results of the ballot box was a product of a series of conflicts between incumbents and their opponents to define the powers of the executive branch of government. By doing so, I suggest that a shift be made to much more overtly political accounts of the development of democracy in Costa Rica in which individual actions - as well as their institutional determinants - are recognised, dissected and explained.

Secondly, I also identify the implications of such an explanation for comprehending the role played by institutional arrangements in political development, both in and outside of Latin America. As the Costa Rican case illustrates, the struggle for state power itself can often generate severe partisan cleavages and thus prevent the development of democratic institutions. Explaining the democratisation of a political system thus, requires showing how institutional arrangements shape the pursuit of state power and how this struggle itself forges the institutionality of the state.

The first section of the article evaluates the usefulness of existing, largely sociological ways of explaining the development of a democratic regime in Costa Rica. I then discuss the institutional foundations of presidential power and delineate the trend towards more democratic forms of government since the late nineteenth century. In the final section, I identify the implications of my analysis for existing accounts of the democratisation of the Costa Rican polity and for prevailing discussions of the origins of different regime types in Latin America.

\section{The origins of democracy in Costa Rica: explanations and evidence}

Most foreign and domestic observers concur that the distinctiveness of Costa Rican politics stems from its atypical experience during the colonial period. The absence of large numbers of resident Indians and the lack of mineral resources made Costa Rica unattractive for extensive Spanish settlement. Unlike other parts of the Spanish Empire, Costa Rica was underpopulated as well as poor for most of its history. Those who did live in colonial Costa Rica, according to these views of Costa Rican history, developed a rural egalitarian society that proved to be an ideal foundation for democratic government. ${ }^{4}$

4. Perhaps the most influential version of this thesis remains that of Carlos Monge Alfaro, Historia de Costa Rica (San Jose, 1966). Other notable examples include: Oscar Aguilar Bulgarelli, Ensayos de la historia patria (San José, 1984); José Albertazzi Avendaño, 'Linos apuntes simples sobre la democracia costarricense', Don José Albertazzi y la democracia costarricense (San José, 1987 [originally published in 1940]); Eugenio 


\section{Fabrice Edouard Lehoucq}

Echoing the arguments first made by Barrington Moore, others argue that Costa Rica's uncommon political trajectory is the product of a class structure spawned by the cultivation of coffee since the mid-nineteenth century. ${ }^{5}$ The scarcity of labour, along with the abundance of land, fuelled the growth of a large class of small and medium-sized property-holders who both cultivated coffee for export and participated in the emerging rural wage economy. Unlike the rest of Central America, these analysts point out, large landlords in Costa Rica did not have to compel the rural workforce to work on their estates. Without the need for coercion, landlords did not have to pressure public officials to create the security forces necessary to maintain a steady supply of labour and to repress peasants, workers and others who threatened their control over the state.

Though I am questioning the claim that the development of an open, competitive political system springs from such a society, it is clear that Costa Rican rural relations have not been characterised by large-scale conflicts between landlords and a large mass of landless peasants. Class struggle instead took the form of a series of conflicts between what is

Rodríguez Vega, Apuntes para una sociología costarricense (San Jose, 1979 [originally published in 1953]) ; José Francisco Trejos, Origeny desarrollo de la democracia en Costa Rica (San José, 1939). Useful surveys include Chester J. Zelaya, Democracia con justicia social y libertad ', in Chester J. Zelaya (ed.), Democracia en Costa Rica? cinco opinions polémicas (San José, 1983) as well as Marc Edelman and Joanne Kenen, La culture politique du Costa Rica', Les Temps Moderns, No. 517-518 (August/September 1989). The principal English-language proponents of this explanation are James L. Busey, Notes on Costa Rican Democracy (Boulder, 196z); Charles D. Ameringer, Democracy in Costa Rica (New York, 1982); John A. Booth, ' Costa Rica: The Roots of Democratic Stability', in Larry Diamond, Juan J. Linz and Seymour Martin Lipset (eds.), Democracy in Developing Countries: Latin America (Boulder, 1989); Samuel Z. Stone, The Heritage of the Conquistadors (Lincoln, 1991).

5 Barrington Moore, The Social Origins of Dictatorship and Democracy: Lord and Peasant in the Making of the Modern World (Boston, 1966). For a similar sort of study with a larger sample of cases, see Dietrich Rueschemeyer, Evelyne Huber Stephens and John D. Stephens, Capitalist Development and Democracy (Chicago, 1992). For Moorean interpretations of Central America, see Enrique Baloyra-Herp, 'Reactionary Despotism in Central America', Journal of Latin American Studies, vol. 15, no. z (1983); Lowell Gudmundson, ' Lord and Peasant in the Making of Modern Central America', in Evelyne Huber Stephens and John Stephens (eds.), Agrarian Structure and Political Power in the Period of Export Expansion (Pittsburgh, forthcoming); David Kauck, 'Agricultural Commercialization and State Development in Central America : The Political Economy of the Coffee Industry from 1838 to 1940 unpubl. Ph.D. disc., University of Washington, 1988; Jeffrey Paige, ' Coffee and Politics in Central America', in Richard Tardanico (ed.), Crisis in the Caribbean Basin (Beverly Hills, 1987); Hector Perez Brignoli, Crecimiento agroexportador y regímenes políticos en Centroamérica : un ensayo de Historia comparada', in Hector Perez Brignoli and Mario Samper (eds.), Tierra, café y sociedad: Ensayos sobre la Historia agraria centroamericana (San José, 1994); John Weeks, 'An Interpretation of the Central American Past', Latin American Research Review, vol. 21, no. 3 (1986). 
often labelled a 'rural middle class' and the owners of coffee exporting firms (beneficiadores) over the price paid at harvest time by the latter to the former. The magnitude and frequency of rural protest began a long-term decline by the early 1930s, when small and medium-sized coffee growers settled their differences with coffee exporting firms by creating a government agency to regulate the price of coffee. ${ }^{6}$ Though the number of landless peasants has steadily increased since the late nineteenth century, ${ }^{7}$ they - or urban-based artisans and workers - never became the basis of powerful counter-hegemonic social movements. ${ }^{8}$

Neither have other destabilising cleavages emerged in Costa Rica. The secularisation of political authority in the late nineteenth century did not trigger a long-lasting conflict between opponents and proponents of an important role for the Roman Catholic Church in public affairs. ${ }^{9}$ Though civil and religious authorities did clash in the 1870s and 1880s, this struggle only briefly contributed to shaping patterns of party behaviour before dissipating by the turn of the century. And, despite the presence of an Afro-Caribbean population in the Atlantic Coast Province of Limón, the racial homogeneity of most Costa Ricans living in the central valley has prevented the emergence of virulent and ethnically based politics in this country. ${ }^{10}$

It is precisely this generalised social consensus that is responsible for the widely held view that the democratisation of the Costa Rican polity was unavoidable. While the absence of long-term, simmering disputes has reduced the number and intensity of social and economic cleavages, Costa Rican politicians have often disregarded the results of the ballot box. They may have failed to transform social and economic conflicts into enduring partisan cleavages, but they turned the struggle for state power into a series of strife-torn clashes and occasionally bloody confrontations.

Until the late nineteenth century, for example, most chief executives were selected in essentially non-competitive (and indirect) elections or

6 Víctor Hugo Acuña Ortega, Patrones del conflicto social en la economía cafetalera costarricense (1900-1948) Revista de Ciencias Sociales (San José), no. 31 (March 1986).

7. Lowell Gudmundson, ' Peasant, Farmer, Proletarian : Class Formation in a Smallholder Economy, 1850-1950', Hispanic American Historical Review, vol. 69, no. z (May 1989) and Mitchell A. Seligson, Peasants of Costa Rica and the Development of Agrarian Capitalism (Madison, 1980).

8. Víctor Hugo Acuña 0. and Iván Molina Jimenez, Historia económica y social de Costa Rica (San José, 1991).

9 Claudio Vargas, El liberalism", la Iglesia y el Estado en Costa Rica (San José, 1991).

10 See Philippe I. Bourgois, Ethnicity at Work: Divided Labor on a Central American Banana Plantation (Baltimore, 1989); Aviva Chomsky, 'A Perfect Slavery:' West Indian Workers and the United Fruit Company in Costa Rica, 1870-19f" (Baton Rouge, forthcoming) and Trevor Purcell, Banana Fallout: Class, Color, and Culture among the West Indians in Costa Rica (Berkeley, 1993). On the relation betweem ethnicity and political instability, see : Donald L. Horowitz, Ethnic Groups in Conflict (Berkeley, 1985). 


\section{Fabrice Edouard Lehoucq}

assumed office as legal designates for brief periods of time. Seven chief executives in Costa Rica came to power through the force of arms, one of whom constructed a dictatorship that lasted nearly a dozen years. Two presidents had the misfortune of being summarily executed after having become the victims of coups. Only one chief executive was chosen in a competitive election while all others assumed power as legal designates for brief periods of time or were selected in essentially non-competitive elections.

Only in the aftermath of Tomás Guardia's dictatorship (1870-82) did politicians begin to rely upon the ballot box to select key public officials. As Figure 1 shows, seventeen presidents have been selected in fair and competitive elections since the late nineteenth century. Four others have assumed office as a result of extra-constitutional arrangements reached by parties in the aftermath of inconclusive elections. Five chief executives have been appointed as legal designates.

Even as Costa Rican presidents increasingly have become selected in fair and competitive elections, the struggle to hold or to maintain control of the executive branch of government has not always remained peaceful. Since 1882, outgoing presidents have imposed their successors on at least six different occasions. During the same period also, opposition movements have launched twenty-six rebellions against central state

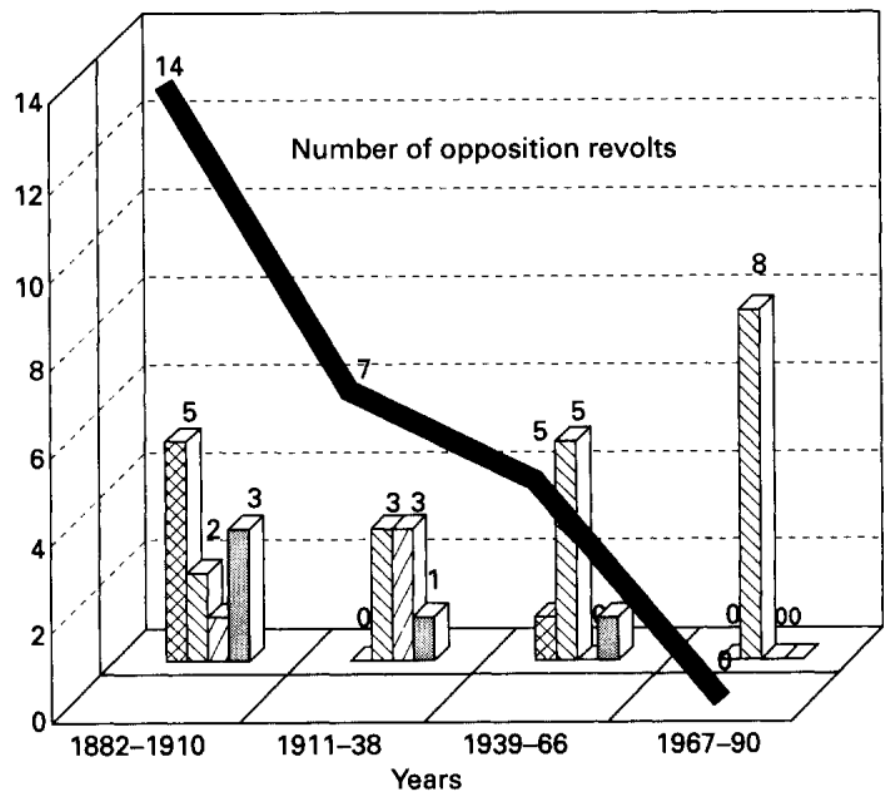

Fig. I. Presidential succession and opposition rebellions, $1882-1990$. Sources: see footnote i I and

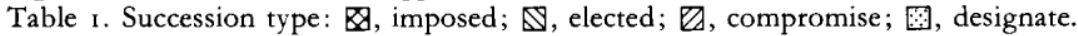


authorities - three of which succeeded in installing a new incumbent in the presidency. Disputes regarding the results of the 1948 presidential elections became so intense that a faction of the opposition started a civil war that led to the death of between I,000 and 1,300 individuals. ${ }^{11}$ The use of violence and fraud to capture state power only declined in the aftermath of the 1948 civil war.

The causal validity of existing, largely sociological accounts of democratisation in Costa Rica is also placed in doubt by political developments in two other Latin American countries. Despite living in a largely agrarian economy characterised by oppressive class relations, politicians in Chile began to compete for state power within the electoral arena by mid-nineteenth century. Until Pinochet's rise to power in a coup in 1973, Chileans had lived in perhaps one of the most long-lasting democratic regimes in the world. ${ }^{12}$ The utility of these approaches also is placed in doubt by their inability to explain why democratic practices have failed to endure during the twentieth century in Argentina, a country long possessing the attributes of modernity. ${ }^{13}$

Comparative evidence, along with the behaviour of Costa Rican politicians, suggests that consensual social structures do not automatically produce democratic regimes. The absence of multiple and divisive cleavages may facilitate, but does not guarantee, cooperation among politicians. Explaining the development of democratic institutions thus requires shifting away from establishing linkages between social conditions and political outcomes to explaining why politicians decide to comply with the results of the ballot box.

\section{Presidentialism and political competition}

By focusing on the behaviour of individuals, I do not suggest that the cultural or sociological characteristics of politicians encourage them to comply with democratic institutions. That many Costa Ricans acknowledged as well as disregarded the results of the ballot box underscores the limited utility of norm-based explanations of political behaviour. I also refrain from speculating on the role played by cultural values in decisionmaking because of the difficulty of measuring the importance of a norm

11. John W. Gardner, ' The Costa Rican Junta of 1948-49', unpubl. Ph.D. diss., St John's University, 1971, pp. 54-5. Data on presidential succession during this period are from Fabrice Edouard Lehoucq, ' The Origins of Democracy in Costa Rica in Comparative Perspective', unpubl. Ph.D. diss., Duke University, 1992, pp. 63-7o. Data on the period prior to 1882 are from Busey,

' The Presidents of Costa Rica '.

12 Arturo Valenzuela and J. Samuel Valenzuela, ' Los orígenes de la democracia'.

13. H. Waisman, Reversal of Development in Argentina: Postwar Counterrevolutionary

Policies and their Structural Consequences (Princeton, 1987), pp. 94-126. 
to a person (or a group) without relying upon observations of her (or their) behaviour. ${ }^{14}$ Recent efforts to circumvent these methodological limitations conclude that cultural attitudes do not decisively influence whether a democratic regime does or does not emerge. ${ }^{15}$

To make sense of the choices made by politicians, this article builds upon the central premises of rational choice analysis. ${ }^{16}$ It assumes that politicians want to hold office to shape public policy. It also presupposes that the rules governing access to state offices generate incentives for them to act in fairly predictable ways. Both assumptions generate the proposition that the decision to respect the results of the ballot box is a product of strategic and institutional constraints. Unable to impose their rule on their rivals, politicians settle for what they can get and not what they want.

In what follows, I pursue an inductive strategy to identify the conditions that prompt incumbents and their adversaries to respect and to build democratic institutions. I begin by indicating how the structure of the Costa Rican political system undermined the very cooperation its constitution ostensibly aimed to foment.

\section{The institutional preponderance of the Costa Rican presidency}

The importance of the presidency in Costa Rican political life stemmed from its policy-making pre-eminence and its control of key bureaucratic instruments. Though the 1871 constitution stipulated that all laws needed both executive and legislative approval, it undercut the autonomy of Congress as it endowed the president with a number of exceptional powers. ${ }^{17}$ The constitution only permitted the Congress to hold ordinary

14 See Michael Hechter, Principles of Group Solidarity (Berkeley, 1987), esp. pp. 3-6 and Adam Przeworski, Democracy and the Market: Political and Economic Reforms in Eastern Europe and Latin America (Cambridge, 1991), pp. 19-37.

15 Edward N. Muller and Mitchell A. Seligson, ' Civic Culture and Democracy : The Question of Causal Relationships ', American Political Science Review), vol. 88, no. 3 (September 1994).

16 See especially Tsebelis, Nested Games and Barbara Geddes, ' Uses and Limitations of Rational Choice ', in Peter H. Smith (ed.), Latin America in Comparative Perspective: New Approaches to Methods and Analysis (Boulder, 1995 ). Two other analysts, whose work has influenced my own, use a similar set of assumptions to answer somewhat different questions. They are Barry Ames, Political Survival: Politicians and Public Polity in Latin America (Berkeley, 1987) and Barbara Geddes, Politician's Dilemma: Building State Capacity in Latin America (Berkeley, '994).

17 I refer to the unreformed version of the 1871 constitution unless I state otherwise. I rely upon the version of the 1871 constitution contained in Marco Tulio Zeledón, Digesto constitucional de Costa Rica (San José, 1946), pp. 207-24. It also is reprinted in Hernán G. Peralta, Las constituciones de Costa Rica (Madrid, 1962). The 1949 constitution is discussed below. 
sessions during three months of the year. It empowered the president to call extraordinary sessions of the legislature to consider issues of its choosing throughout the remaining months of the year. The president was allowed to convene the Permanent Commission, a quasi-legislative body composed of five deputies selected by their colleagues, to seek temporary approval of emergency decrees when Congress was not in session. These attributes furnished chief executives with the capacity to revoke individual guarantees by suspending the constitutional order.

Effective control of three ministries determined whether presidents would finish their terms in office. The Ministry of Public Works was a source of jobs that presidents manipulated to reward local authorities for their political loyalty. Through the Ministry of the Interior (Gobernación), presidents controlled the provincial as well as cantonal (municipal) administration of the republic. From within this Ministry, they also named the officials who registered voters, who selected members of local polling stations and who tallied the votes on election day. By selecting the officers and staff of the Ministry of Public Security (named the Ministry of War and Navy until 1923), presidents also protected their regimes, defended national sovereignty and possessed the coercive authority to enforce the laws of the state. Political competition, in a system that endowed the executive branch of government with such powers, thus revolved around either retaining or acquiring control of the presidency.

\section{The President's dilemma: to hold or not to hold fair elections}

According to the 1871 constitution, incumbents could not run for office until another individual had exercised the powers of the presidency for the four-year term following their own. Candidates were obliged to attract the support of more than 50 per cent of the vote to be named president. Should no one succeed in doing so, members of the new Congress were empowered to select the president on 1 May from among the two individuals receiving the two largest pluralities of the vote. ${ }^{18}$

18 In lieu of popularly elected vice-presidents, legislative deputies selected three presidential designates during the first session of the new Congress. An amendment to the constitution in 1926 established double-ballot elections for the presidency : should no candidate receive an absolute majority of the popular vote, the old Congress on March was to have convened a run-off election among the two candidates who attracted the most votes. In 1936, another constitutional reform decreed that a candidate needed to attract the largest plurality and only $4 \mathrm{o}$ per cent of the popular vote to have been declared president. In the event that no candidate should satisfy these requirements, a run-off election, announced by the old Congress on $1 \mathrm{March}$, would have been held among the two leading candidates during the first Sunday of the following April.

The 1949 Constitution abolished the system of congressionally elected presidential designates and created the office of the vice-presidency. Since 19.53, two vice-presidents 
Despite constitutional provisions aiming to ensure the rotation of public offices among political forces, the centrality of the presidency in public affairs encouraged incumbents to retain state power. Relinquishing control of the presidency would result in the loss of control over state patronage and, more generally, their ability to enact policies beneficial for their constituents. Most importantly, defeat in a presidential election would deprive incumbents of control over the electoral process. Upon yielding power, they could become targets of persecution and would have few guarantees that their rivals would hold equally fair elections. The very attributes that made holding the presidency so desirable thus led to the deformation of what was an ostensibly democratic constitution.

The behaviour of Costa Rican politicians supports this model of political competition. Until well into the twentieth century, most presidents did not come to power in fair and competitive elections. As Figure i reveals, only five out of eighteen presidents between I882 and 1938 were selected in non-fraudulent and open elections. During this same period, opposition factions organised twenty-one insurrections against central state authorities.

Figure i also, however, shows that incumbents did begin to abstain from imposing themselves or their successors on the presidency. It reveals that members of the opposition began to desist from overthrowing governments. Increasingly larger numbers of presidents have come to power in free and competitive elections since the late nineteenth century. Why did Costa Rican politicians begin to eschew the use of force to retain or to gain control of the state? Why did they begin to comply with the results of the ballot box?

Incumbents and opposition movements in Costa Rica began to find peaceful ways of choosing chief executives to prevent the chronic instability generated by the use of violence and fraud. Incumbents recognised that the abuse of presidential prerogatives increased the likelihood that their regimes might be overthrown. Opposition movements gradually came to realise that most rebellions against central state authorities ended in failure, death and destruction. In these circumstances, compromise offered an attractive solution to regulating access to key public offices.

Fear of being overthrown was not the only reason that incumbents or

have been elected along with the president at four-year intervals. In 1969, legislators enacted a constitutional amendment prohibiting an individual from ever being president for more than one four-year term. The only individuals exempted from this ban on re-election were those who had exercised the powers of the presidency before the 1949 constitution was amended to this effect. 


\section{Table I. Rebellions and the legislative influence of presidents in Costa Rica, I $890-1990$}

$\begin{array}{cc}\begin{array}{c}\text { Percentage of legislative } \\ \text { deputies belonging to the } \\ \text { president's party (Number } \\ \text { of elections are placed } \\ \text { in parentheses) }\end{array} & \begin{array}{c}\text { Number of rebellions } \\ \text { launched by members of the } \\ \text { opposition between } \\ \text { legislative elections }\end{array} \\ 53.5(25) & \text { None } \\ 68.7 \text { (II) } & \text { One } \\ 77.3 \text { (3) } & \text { Two }\end{array}$

Sources: Data on the legislative affiliation of deputies between $1890-1948$ are taken from Lehoucq, 'The Origins of Democracy in Costa Rica in Comparative Perspective', unpub. Ph.D. dissertation (Duke University, 1992) p. 80. For the 1949 legislative results, see Tribunal Supremo de Elecciones, 'Declaratoria de elecciones (22 October 1949)', La Gaceta, 25 October 1949; between 1953 and 1982, see Wilburg Jiménez Castro, Génesis del gobierno de Costa Rica, I821-1981, vol. I (San José, 1986), Pp. I $37-8$; and, finally, for 1986 and 1990 , see Tribunal Supremo de Elecciones, Cómputo de votos y declaratorias de elección (San José, 1987, I991). With four exceptions, data on rebellions stem from Rafael Obregón Loría, Conflictos militares y políticos en Costa Rica (San José, I95 I), Pp. 80-I I 6. Information on the 1946 ('el almaticazo') and 1947 ('la buelga de brazos caidos') rebellions was collected from John Patrick Bell, Crisis in Costa Rica: The 1948 Revolution (Austin, 1971). The 1949 barracks revolt has been studied by Guillermo Villegas Hoffmeister, El cardonazo (San José, 1986) and the 1955 invasion launched by calderonistas in Miguel Acuña, El ss (San José, 1977).

Notes: Parties only appeared in Costa Rica during the $1889-90$ elections. The partisan affiliation of deputies during the midterm $\mathrm{I} 900$ election remains unidentified. Data for $19 \mathrm{I} 8$ are not included because, between 1917 and 1919, a dictatorship existed in Costa Rica.

their adversaries began to participate in increasingly fair and competitive elections for the presidency. Unless incumbents were compensated for acknowledging their defeat at the polls, they were unlikely to relinquish control of the presidency. Similarly, if electoral defeat implied the absence of political influence, members of the opposition also were unlikely to refrain from attempting to topple the president. Incumbents, along with their adversaries, began to consider recognising the results of presidential elections once they were at least guaranteed access to other important public offices.

Analysis of congressional electoral results and the timing of rebellions indicates that political competition tended to remain peaceful if those parties that failed to capture the presidency were nevertheless compensated by being allowed to occupy seats in Congress. Table 1 shows that the average share of legislators belonging to the president's party was 77 per cent during periods when the opposition attempted to overthrow the opposition on two different occasions. It fell to nearly 69 per cent during intervals when the opposition organised one insurrection against the government. The proportion dropped to slightly more than half of the 


\section{4 o Fabrice Edouard Lehoucq}

delegation sent to Congress during periods when the adversaries of the president refrained from using the force of arms to gain control of the state. ${ }^{19}$

Data on the legislative strength of insurgents reveal that groups with a stake in the political system became dissuaded from organising insurrections against central state authorities. Figure 2 shows that the political forces that attempted to overthrow the president between 1890 and 1948 only controlled a minority of legislative seats. With only a pair of exceptions, most possessed ten or less than 1 TO per cent of the delegation biennially sent to Congress. Few revolts were backed by legislators who also controlled the balance of power within Congress. Only the insurrections of 1930 and 1932 were led by individuals whose associates in the legislature could form majorities (of 53 and 70 per cent, respectively) with pro-government deputies.

The evidence presented in this section suggests that democratic stability was a product of decisions made by incumbents and their opponents to share and not to monopolise state power. Under the threat of being overthrown, incumbents began to permit electoral competition to select the occupants of executive and legislative offices. The ability to send representatives to Congress also encouraged ruling and opposition parties to start respecting the results of the ballot box. Concerned with their political survival, incumbents and their rivals struck a bargain whose by-

19 Legislative deputies have been elected from one of seven districts whose boundaries correspond to those of Costa Rica's seven provinces. Between 1882 and 1893, individuals who attracted the largest pluralities of votes in each district became Congressmen. Provinces that sent two or fewer representatives to Congress required candidates to gain absolute majorities between 1893 and 1913. Districts that elected three or more Congressmen allocated seats through proportional representation during this period. Between 1913 and 1946, provinces that sent two or fewer representatives to Congress required candidates to attract relative majorities of the vote. In those that sent three or more deputies to the legislature, a system of proportional representation was employed to distribute congressional seats. Since 1946, all deputies have been elected through the least remainders version of proportional representation in seven provincial electoral districts.

Until 1948, congressional elections were held every two years for half of its members, each of whom served a four-year term in office. A constitutional prohibition against re-election for legislators only came into effect with the promulgation of the 1949 constitution. Since 1949, all members of the newly named Legislative Assembly have been elected to four-year-terms that they serve co-terminously with that of the president. Legislative deputies may run for re-election, but are constitutionally required to wait for a period of four years before running for office.

Electoral laws and their reforms were initially printed in the daily government newspaper, La Gaceta: Diario Oficial, and subsequently published in La Colección de Leyes y Decretos (San Jose, 1882-). Versions of electoral laws were also published as booklets ; they will be cited below. For a juridical analysis of the current law, see Ruben Hernández Valle, Derecho electoral costarricense (San Jose, 1989). 


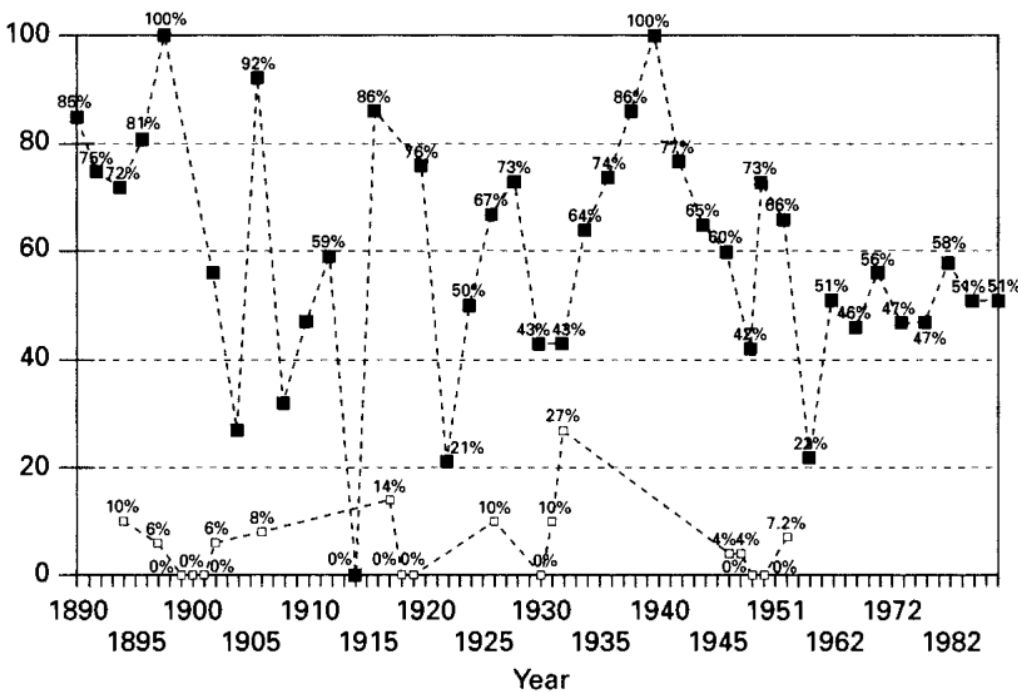

Fig. 2. Legislative strength of insurgent and pro-government deputies, I890-1990. Sources: same as Table I. This figure does not contain data for 1900 or 1918 . $\square$, Insurgents; $\boldsymbol{\square}$, progovernment.

product was the gradual increase in rates of compliance with democratic institutions.

\section{Institutional reform and the development of democratic stability}

This mutually beneficial arrangement depended upon the willingness of incumbents to exchange public office for political stability. The temptation always existed for incumbents to employ the powers of the presidency to influence the nature of electoral outcomes, especially if they believed they had more to gain from retaining rather than from relinquishing control of the executive. In a political system that endowed the presidency with so much authority, opposition movements held few guarantees that state officials would respect the rules of democratic political competition. Uncertainty and instability were largely unavoidable consequences of the 1871 constitution.

In such an environment, opposition parties focused upon preventing the president from enacting legislation without the approval of Congress and upon restricting his ability to manipulate electoral laws for partisan advantage. Tying the hands of the incumbent promised to facilitate the detection of all transgressions of previously negotiated agreements made between presidents and opposition forces. More importantly, doing so held out the possibility of increasing the number of opposition 
representatives in Congress, from where anti-government forces could more effectively contest the authoritarian proclivities of standing presidents.

The restructuring of political institutions, however, was difficult because most incumbents and majority parties proved unwilling to curtail the powers of their offices. Even when an incumbent favoured change, tendered reforms often needed the support of super-majoritarian legislative coalitions. Altering or creating laws regulating the powers of the presidency, for example, initially required endorsement by committee and, subsequently, approval by congressional majorities on three separate readings of the bill. In addition to following the rules governing the creation or alteration of ordinary laws, attempts to amend the constitution only succeeded after they had received the backing of two-thirds of all deputies in two different years of the legislative calendar.

Yet, on a number of important occasions, reformist coalitions overcame the natural resistance of incumbents, majority party deputies and, in the case of electoral reform, those representing local machines, for whom support of genuine reform meant political suicide. Aided by handfuls of pro-government and independent depuities, presidents and their nominal opponents gradually succeeded in reducing the powers of the presidency. By endorsing far-reaching reforms, incumbents not only stabilised their regimes, but also created reputations for themselves as change-oriented politicians. Opposition legislators cooperated with presidents because doing so increased the likelihood that their parties would obtain control of key public offices. Acting together, they transformed the institutional landscape of Costa Rican politics.

According to the 1871 constitution, presidents were entitled to convene the Permanent Commission to deliberate on matters requiring immediate attention during the nine months of the year when Congress was not in session. The five members of the Permanent Commission were selected by their colleagues at the end of the ordinary sessions of Congress. Its most important attribute consisted of the suspension of the constitutional order at the petition of the chief executive. When combined with the responsibility for organising and holding elections, the authority to convene the Permanent Commission furnished presidents with the power to prevent their opponents from capturing key public offices.

Between 1882 and 1910 presidents declared states of siege on seventeen occasions, eleven with the endorsement of the Permanent Commission and five with the consent of Congress. Only on one opportunity did an incumbent unilaterally abrogate the constitutional order after he had illegally dissolved Congress. Presidents also used states of siege to suppress armed movements five out of the eleven times they gained the 


\section{Table 2. Political repression and the Permanent Commission in Costa Rica, I882-19IO}

\begin{tabular}{|c|c|c|c|}
\hline $\begin{array}{l}\text { Type of presi- } \\
\text { dential action }\end{array}$ & $\begin{array}{c}\text { Unilaterally } \\
\text { taken }\end{array}$ & $\begin{array}{c}\text { Endorsed by the } \\
\text { Permanent } \\
\text { Commission }\end{array}$ & $\begin{array}{c}\text { Endorsed by } \\
\text { Congress }\end{array}$ \\
\hline Suppressing revolts & & s & 4 \\
\hline $\begin{array}{l}\text { Manipulating electoral } \\
\text { laws }\end{array}$ & & 3 & \\
\hline Dissolving Congress & I & & \\
\hline Persecuting opponents & & & 3 \\
\hline
\end{tabular}

support of the Permanent Commission during this period. On three other occasions, presidents employed this device to jail and to exile their opponents. Table 2 summarises these results.

Throughout most of this period, opposition parties retaliated by trying to topple successive governments. Their efforts forced President Rafael Iglesias Castro (1894-1902) - the only chief executive to succeed himself in office - to endorse, along with the moderate sector of the opposition, the compromise candidacy of Asención Esquivel Ibarra (1902-6).

The fear that the president would employ the Permanent Commission to suspend the constitional order again became real towards the end of the campaign to select a new president and one-half of the members of Congress in 1906. Under the pretext that hardline opposition factions were plotting a coup against his government, Esquivel Ibarra obtained the support of the Permanent Commission to declare a state of siege on I March 1906. Deprived of their rights, large numbers of opposition electors were either coerced into voting for official candidates or thrown into jail. Through the use of violence and fraud, Cleto Gonzalez Víquez was installed in the presidency and furnished with a large congressional majority. ${ }^{20}$

Prevented from occupying executive and legislative offices, a movement led by leading Republicans attempted to capture the army barracks in Puntarenas and Liberia in the hopes of igniting a revolt against Gonzalez Víquez's regime. ${ }^{21}$ Though these insurgents failed to secure control of the barracks, their efforts did trigger what became a four-year period of

20 Orlando Salazar Mora, El apogeo de la república liberal en Costa Rica (187o-1914) (San José, 1990), pp. $211-22$.

21 Octavio Quesada, Sumaria por sedition: noviembre, diciembre de 1906 (San José, 1906). 
negotiations between the government and opposition about the nature and extent of presidential powers. Under the threat of being overthrown, President Gonzalez Víquez helped to reform electoral laws (discussed in the next section) and reluctantly began to consider opposition demands to abolish the Permanent Commission and to restrict the ability of the president to suspend the constitutional order.

Efforts to change the constitution intensified in the wake of the Republican Party victory in the 1908 midterm elections, which substantially reduced the government's previously overwhelming majority in Congress. That forecasts of the approaching 1910 general elections suggested that the Republicans would win both the presidency and a majority in Congress succeeded in encouraging many gonzalista deputies to abandon backing all government policies. Along with favourable electoral trends, compromise on the proposed reforms allowed the opposition Republicans to fashion a coalition in support of their proposed constitutional reforms. ${ }^{22}$

Faced with a two-thirds congressional majority in favour of constitutional change, President González Víquez endorsed the Republicaninspired project calling for the dismantling of the Permanent Commission and for restricting the ability of the chief executive to declare states-ofsiege. Henceforth, the president's decision to suspend the constitution when Congress was in recess also entailed the holding of an extraordinary session of Congress within forty-eight hours of the date of such a decree. Through a simple majority of votes, the emergency meeting of Congress then became empowered to cancel the order announcing a state-of-siege. In the aftermath of the Republican Party's overwhelming victory at the polls a year later, the tendered reforms were promulgated during the initial year of Jimenez Oreamuno's first term in office $(1910-14) .{ }^{23}$

\section{Limiting presidential discretion: the reform of electoral laws}

Electoral reform was the other objective pursued by critics of presidential power in Costa Rica. Unlike the struggle to abolish the Permanent Commission, however, opposition to institutional change did not stem solely from the unwillingness of incumbents and pro-government legislators to relinquish their ability to suspend the constitutional order

22 Lehoucq, ' The Origins of Democracy in Costa Rica in Comparative Perspective', pp. $88-9 z$. Unless otherwise stated, data on the partisan affiliation of deputies are from Table 1. 23

23. Orlando Salazar Mora, 'La Comisión Permanente y la suspension del orden constitutional', Revista de Ciencias juridicas (San José, Costa Rica), No. 44 (May-August 1981), pp. 45-7. 
for partisan advantage. Politicians belonging to locally based political machines, for whom fairer electoral practices represented political suicide, also blocked efforts to purge electoral laws of fraud-ridden procedures. Under the threat of being deposed, a handful of change-oriented incumbents fashioned an alliance of convenience with important elements of the opposition to prevent the armed confrontations that both wished to avoid. Helped by small numbers of pro-government and independent deputies who preferred stability to civil war, reformist incumbents and their rivals transformed key institutions in the hopes of improving their ability to capture larger shares of state power.

The 1871 constitution restricted suffrage rights to men at least twenty years old who, because of property or employment, had an adequate standard of living or to men at least eighteen years old who were either married or ' professors of some science'. It also stipulated that presidential and congressional elections were public and indirect : citizens voted for electors who subsequently cast ballots for the president and for legislative deputies in provincial electoral colleges. ${ }^{24}$

The 1871 constitution ostensibly empowered both the executive and legislative branches of government with the responsibility of certifying electoral results. For example, it furnished Congress with the responsibility of ensuring that presidents were chosen in accordance with constitutional precepts and decided whether newly elected deputies joined its ranks. The pre-eminence of the chief executive in electoral matters, however, was a product of the fact that most procedures of electoral administration were delineated by a specialised body of law. The president's ability to name the officials responsible for producing lists of voters, for holding elections and for tallying the vote thus stemmed from these electoral laws.

Electoral reforms were not seriously discussed and enacted until the reformist presidency of Gonzalez Víquez (1906-10). ${ }^{25}$ After defeating an insurrection against his government in November 1906, the president and his Republican adversaries, over the next three years, passed three major sets of reforms of the 1893 Law of Elections. Henceforth, the president of

24 A constitutional reform in 1913 eliminated indirect elections for all public officials. The 1949 National Constituent Assembly made the franchise universal to include all male and female Costa Ricans above the age of twenty. A constitutional amendment in 1971 lowered the voting age to eighteen.

25 The electoral law then in effect was enacted in the early 189os. See: 'Ley de elecciones

Nov. 1893)\% Decretos relatives a elecciones: instrucciones para practicar las de segundo grado, conforme al sistema de voto proporcional numéricoy division territorial electoral (San José, 1893). Discussions of its legal provisions include: Nelson Chacón Pacheco, Reseña de nuestras leges electorales (San José, 1975) and Orlando Salazar Mora, 'El sistemas electoral costarricense: un análisis del período 1889-1919', Avances de Investigación, No. zo, Centro de Investigaciones Históricas, Universidad de Costa Rica (San José, 1986). 
provincial Electoral Assemblies was to be chosen by lot from among six candidates nominated by the Supreme Court of Justice. The presence of opposition party representatives (fiscales) on all electoral juntas, each of whom was entitled to supervise all election procedures and to file complaints regarding the fairness of electoral results (demandes de nulidad), undercut the power of presidential appointees to manipulate results for partisan advantage. ${ }^{26}$

\section{The 1913 Law of Elections}

Encouraged by the first Republican president of Costa Rica, Ricardo Jimenez Oreamuno (1910-14), ten deputies proposed that all elected officials be chosen in direct elections by citizens through the secret franchise. ${ }^{27}$ Along with increasing the safeguards held by opposition parties, this project aimed to eliminate the period of time between first and second stage elections that frequently generated the instability prompting presidents to suspend the constitutional order.

Even if they possessed the support of the president, these reforms could be blocked by one-third of the total membership of Congress. Though the Republicans had done extraordinarily well in the 1910 elections, only about half of the 41 deputies belonged to the jimenista faction of the party. The remaining Republican deputies were loyal to Deputy Fernández Alvarado, a politician long feared by his opponents because of the powerful political machine he directed. ${ }^{28}$ Even after the 1912 mid-term elections, when the jimenistas captured 13 of the 22 seats subject to competition, the president could only count upon the support of 23 of the 41 deputies in Congress.

Opposed by a coalition of machine politicians, most of the tendered constitutional reforms failed to muster the two-thirds legislative support (29 out of 41 deputies) required for initial passage of all such bills. By a vote of 24 to 18, the secret franchise was defeated on 4 June 1912 and thus failed to obtain the support necessary to be forwarded to next year's session of Congress. ${ }^{29}$ Only the measure eliminating two-stage elections for the presidency and for legislatures succeeded in garnering the support of a sufficiently large number of deputies. Slightly less than a year

26 They were 'Ley No. 28 (1 Dec. 1908)', 'Ley No. 3o (zz May 1909)', 'Ley No. 73 (26 June 1909)'. All reforms of the 1893 Law of Elections in effect for the 1910 general elections are included in Compilación sabre Leyes de Elecciones (June 1909) (San Jose, 1909). 27 'Proyecto (June i910)', La Gaceta, No. 137 (8 July 1910), p. z8.

28 Orlando Salazar Mora, Máximo Fernández (San José, 1975). Unless otherwise stated, data on the partisan affiliation of deputies are from Table

29 Constitutional Congress, Ordinary Session No. zz (4 June 1912), article 5, La Gaceta, No. 131 (13 June 1912), p. 713. 
later, a two-thirds legislative majority approved this reform after it was endorsed and returned by the president to Congress. 30

Despite the failure of these projects, President Jimenez Oreamuno sent Congress a new Law of Elections in the Spring of 1913. Seeking to avoid the need to garner the support of a two-thirds legislative majority required by constitutional amendments, Jimenez Oreamuno's project proposed that literate citizens could vote secretly and those who were not would vote publicly. Though Congress enacted a new electoral law later that year, deputies stripped Jimenez Oreamuno's electoral reform bill of its system of mixed voting. ${ }^{31}$ The principal innovations of the 1913 Law of Elections consisted of the modernisation of the safeguards protecting the interests of opposition parties initially enacted during the presidency of Gonzalez Víquez (1906-10). ${ }^{32}$

\section{The 1925 and 1927 electoral reforms}

Opponents of electoral fraud only succeeded in establishing the secret franchise somewhat more than a decade later. Reform-oriented politicians were able to transform electoral laws because they exploited the advantages furnished by a peculiar balance of power between the executive and legislative branches of government.

No party had obtained the constitutionally required absolute majority of the popular vote in the 1924 elections. In line with existing constitutional statutes, Congress became responsible for selecting the new president from among the two candidates who had polled the largest number of votes. The selection of Alberto Echandi Montero of the Agricultural Party (37 per cent of the popular vote) or of Jimenez Oreamuno of the Republican Party (42 per cent of the popular vote) hinged upon the final tally of legislative results. In a manoeuvre lambasted by the Agricultural Party, two Provincial Electoral Juntas - controlled by the Republicans and its new found ally, the Reformist Party - tallied the popular vote in such a way as to deny this party control of an outright majority in Congress. An alliance of the Republican and Reformist legislators then selected Jimenez Oreamuno to become president."

30 Constitutional Congress, Ordinary Sessions No. i i (15 May 1913), article 6, La Gaceta, No. I 14 (21 May 1913), p. 6o5. These reforms were published as Decreto no. 7 (17 May 1913)', La Gaceta, No. 128 (7 June 1913), pp. 673-4.

31 Dictamen de la Comisión de Legislación (zo June 1913) ', La Gaceta, No. 146 (z8 June 9.3), PP. 773-4.

32 'Ley de elecciones (7 August 1913)', Colección de Leyes y Decretos (San José, 1913).

33 Ramírez A., Jorge Volio y la revolución viviente (San José, 1989), pp. 112-46; Marina Volio K., Jorge Volio y el Partido Reformista (San José, 1973), pp. 174-230. The latter is a daughter of the late Jorge Volio Jimenez, who was the leader of the Reformist Party. 
A group of Agricultural Party deputies, two months later, presented their colleagues with a set of electoral reforms - thought just extensive enough to prevent the sort of fraud that had recently deprived their candidate of the presidency. ${ }^{34}$ Later that year, President Jimenez Oreamuno responded by endorsing their effort to reform electoral laws. He, however, stated that he could only support an electoral reform bill that also created the secret franchise, extended suffrage rights to women and established a Civic Registry for the purposes of determining who could and who could not vote. He also suggested that the president should not be entrusted with the power 'to interpret dark passages of electoral law ', so as to prevent the president from becoming 'a grand elector, whom parties illegitimately attempt to persuade to interfere in the electoral process or to attack when they fail to enlist the president as an instrument of their interests '.35

Even though neither Jimenez Oreamuno nor the Agricultural Party possessed an outright legislative majority, such reforms stood a much better chance of being enacted during the mid-1920s than during Jimenez Oreamuno's first term as president. Both the president and the Agricultural Party no doubt realised that electoral reform would be opposed by a sizeable coalition of deputies from all parties that belonged to locally based political machines. The president's ability to veto legislation he disliked forced Agricultural Party deputies either to endorse electoral reforms that included their proposals or to settle for no reform whatsoever. The Agricultural Party's threat to abstain from participating in the 1926 mid-term elections should Congress not enact any reforms also prompted Republican and Reformist deputies to support the project sponsored by 'the president and the Agricultural Party. ${ }^{36}$ Few preferred political instability to reform, especially deputies whose political careers did not hinge upon support from majority parties or from political machines.

Unlike during his first presidency, Jimenez Oreamuno succeeded in fashioning legislative coalitions to enact important electoral laws in 1925 and 1927 because many within the Agricultural Party also supported electoral reform - though initially of a minor sort. By threatening to veto bills that did not incorporate his far-reaching proposals, President Jimenez Oreamuno obliged the opposition to join pro-government and 34 Proyecto (16 June 1924)', La Gaceta, No. 142 (29 June 1924).

35 Importante carta del Presidente de la República acerca de la reforma de la Ley Electoral', Diario tie Costa Rica, No. 1592 (29 Oct. 1924), p.

36. 'El partido agrícola se abstiene de ocuparse en las próximas elecciones de diputados', La Tribuna (3 Feb. 1925), p. 
neutral deputies not entirely dependent upon political machines for their election to Congress to enact a series of fundamental electoral reforms. In 1925, Congress passed an electoral law that established the secret franchise, a registry of voters and the Grand Electoral Council (GCE) to supervise all aspects of electoral administration and to adjudicate conflicting interpretations of electoral law. Two years later, the 1927 Law of Elections replaced the system of party-supplied ballots favoured by machine politicians with a system centralising the production of ballots in the Ministry of the Interior and mandated the distribution of photographic identification cards for all citizens. ${ }^{37}$

\section{The reemergence of instability and the birth of the 1946 electoral code}

Despite these reforms, existing laws still permitted incumbents, majority parties and local political machines to bolster the electoral standing of candidates of their liking. Until the 1940s, governments relieved citizens of the requirement to exhibit photographic identification on election day. Along with the provision that allowed citizens to cast absentee ballots in districts where they were not residents (votos a computar), the lack of photographic identification spawned the development of electoral fraud that permitted governments and political machines to increase their levels of electoral support and to decrease those of their rivals. Estimates suggest that anywhere between 40,000 and 60,000 false identification cards consisting of approximately a fourth to a third of the electorate - existed by the mid-1940s. ${ }^{38}$

The inability of extant legislation to prevent presidents from distorting electoral outcomes permitted Calder\& Guardia (1940-4), once his popularity began to wane, to exclude his opponents from gaining control of legislative and executives offices. The election of Picado Michalski to the presidency in 1944 was widely perceived as a product of Calderón Guardia's machinations, even if analysis of these electoral outcomes reveals that officially sponsored fraud may have contributed to, but may

37 'Se aprobó el dictamen sobre les objeciones del Ejecutivo a la Ley Electoral ', Diario de Costa Rica, No. 1804 (16 July 1925), p. 6. Ley de Elecciones (16 July 1925) (San Jose, 1926). This version contains all subsequent reforms made of the 1925 law. For a description of this law, see Orlando Salazar Mora, 'La Ley electoral de 1925 Avances de Investigación, No. 21, Centro de Investigaciones Históricas, Universidad de Costa Rica (San José, 1986). An analysis of one of its key provisions is Rafael Villegas El Registro Civil y el proceso electoral en Costa Rica', Estudios CIAPA (San Jose, Costa Rica), No. z-3 (1980). For the 1927 law, see: Hector Beeche (ed.), Ley de elecciones (z6 Sept. 1927), (San José, 1931).

38. Lehoucq, ' The Origins of Democracy in Costa Rica in Comparative Perspective', pp. 181, 318-19. 
not have been responsible for, his electoral victory. ${ }^{39}$ Equally destabilising was the marginalisation of the opposition in Congress : between 1940 and 1944, approximately three-fourths of all legislative seats were held by the governing National Republican Party and its ally, the Popular Vanguard Party. By upsetting the delicate balance of power responsible for maintaining political stability in Costa Rica, President Calderón Guardia provoked the formation of groups dedicated to the use of force to capture state power. ${ }^{40}$

\section{Negotiation and institutional reform}

In the spring of 1945, Picado Michalski endorsed a bill aiming to eliminate the president's discretionary authority in electoral matters and to eradicate the ability of pro- as well as anti-government parties to manufacture fraudulent votes. The principal innovations of the proposed Electoral Code included replacing the GCE with the National Electoral Tribunal (TNE) and strengthening its authority to adjudicate conflicts regarding electoral matters and results. The creation of a new Electoral Registry also sought to prevent citizens from casting more than one ballot on election day by assembling an accurate list of individuals entitled to vote and by furnishing each citizen with a photographic identification card.

President Picado Michalski succeeded in promulgating the Electoral Code by relying upon the support of a coalition of opposition and progovernment deputies as well as the votes of a small number of ca/deronista legislators. Locally based machine politicians in all parties, along with most calderonistra deputies, failed to defeat the proposed bill because enough congressmen believed that they could win in honest elections and/or that the consequences of legislative inaction were worse than those of fundamental reform. Reform of existing electoral laws in Costa Rica thus represented an exercise in damage control: important sectors of the ruling bloc recognised that ceding power to the opposition - the most

\section{Ibid. pp. 187-94.}

40 A debate exists regarding the origins of the 1948 civil war. Manuel Rojas Bolaños, Lucha social y guerra civil en Costa Rica, 1940-1948 (San Jose, 1979) and Jacobo Schifter, La face oculta de la guerra civil (San José, 1979) argue that it was the product of class conflict and economic crises. Lehoucq suggests that the 1948 civil war was the outcome of a series of disputes between parties vying for control of the state (see his ' Class Conflict, Political Crisis and the Breakdown of Democratic Practices in Costa Rica : Reassessing the Origins of the 1948 Civil War', Journal of Latin American Studies, vol. 23, no. 1 [Feb. 1991]). Whether the polarisation preceding the civil war was economic or political in inspiration does not matter for the discussion presented here. That it occurred and revolved around electoral guarantees for the opposition, however, is relevant. 
likely effect of electoral reform - was preferable to heightened political uncertainty and the probable outbreak of civil war. ${ }^{41}$

\section{The 1948 civil war}

Despite Picado Michalski's negotiation of mutually benefical agreements with the opposition, relations between the government and its adversaries nevertheless polarised. The death of Cortes Castro in March 1946 decapitated opposition moderates. In their struggle to become leaders of the opposition, hardliners like Jose Figueres Ferrer and Otilio Ulate Blanco discredited all those who still wished to cooperate instead of confront Picado Michalski's government. Once Calderón Guardia declared his presidential candidacy for the 1948 election, the campaign of vilification against the government conducted by opposition hardliners persuaded key opposition moderates that compromise with Picado Michalski would only ensure that his predecessor would be elected president in 1948.

The results of the 1948 presidential election indicated that the opposition's candidate, Ulate Blanco, had defeated Calderón Guardia. Marred by numerous irregularities, the outcome of the election was questioned by many calderonistas, who succeeded in annulling Ulate Blanco's victory in the session of Congress convened on I March to judge the validity of presidential electoral results. In the weeks that followed, efforts to negotiate a pact between pro- and anti-government forces became pointless once the army led by Figueres Ferrer won the civil war and, subsequently, organised a junta to rule Costa Rica for what eventually became a period of eighteen months.

\section{The reform of the 1871 constitution}

During the junta's rule, popularly elected delegates attended a convention to design a new constitution for Costa Rica. ${ }^{42}$ Dominated by the

41 This is the core conclusion of Lehoucq, 'Institutional Change and Political Conflict : Evaluating Alternative Explanations of Electoral Reform in Costa Rica ', Electoral Studies, vol. 14, no. 1 (March 1995). With Iván Molina Jimenez, I am currently writing a manuscript, thanks to the generous support of the U.S. National Endowment for the Humanities, tentatively entitled, Fraud, Electoral Reform and Democracy: Costa Rica in Comparative Perspective, which will explore in much more detail the issues analysed in this section.

42. See Oscar Aguilar Bulgarelli, La constitución de 1949: antecedentesy proyecciones (San José, 2973); Mario Alberto Jimenez, Historia constitucional de Costa Rica (San Jose, 2979), pp. 15469. A discussion of each of the assembly debates is : Ruben Hernández Póveda, Desde la barra: como se discutió y emitió la Constitución Politica de r949 (San José, 1991 [originally published in 1953]). Hernández Póveda covered Assembly sessions as a reporter for the evening newspaper, La prensa libre. 
representatives from Ulate Blanco's party, the National Constituent Assembly rejected the junta's draft constitution calling for a dramatic expansion of the role of the state in domestic affairs. Marginalised within the Constituent Assembly, pro-junta delegates failed to prevent a majority of convention participants from reducing the decree-making powers of the junta. Contrary to the wishes of the junta, the Constituent Assembly settled for restructuring the relations among the branches of government contained in the 1871 constitution. ${ }^{43}$

The 1949 Constituent Assembly strengthened the powers of the legislature as they reduced those of the executive branch of government by restricting the decree-making power of presidents to the execution of existing laws. It expanded the autonomy of the legislature by increasing to six the number of months the Legislative Assembly remained in ordinary sessions. During such periods, both the executive and legislative branches of government can send bills to the Assembly for discussion; during extraordinary sessions, in contrast, the chief executive convenes the Assembly and sets its agenda. The 1949 Constituent Assembly also adopted practices characteristic of parliamentary regimes : it empowered the Legislative Assembly to conduct interpellations of cabinet ministers and to subject them to censure, given two-thirds deputy support. ${ }^{44}$

The most innovative institution created by the Constituent Assembly is the Supreme Tribunal of Elections. To guarantee the sanctity of elections from partisan manipulation, the Supreme Tribunal of Elections is composed of three magistrates and three alternates, each of whom serves staggered, six-year terms and is elected by a two-thirds vote of the members of the Supreme Court of Justice. Made a branch of government equal to the other three in 1975, the Supreme Tribunal of Elections is solely responsible for calling elections, appointing members of all polling stations, interpreting all legal and constitutional provisions relating to electoral matters, investigating claims of illegal practices by officials, tallying the popular vote and declaring the winners of presidential, legislative and municipal elections. ${ }^{45}$

43. Gardner, ' The Costa Rican Junta of 1948-9', pp. 168-21o.

44. See Wilburg Jimenez Castro, Génesis del gobierno de Costa Rica, 1821-101, vol. i (San Jose, 1986); Rose Marie Karpinski de Murillo, et al., Reflexiones sabre el Poder Legislativo costarricense (San José, 1989); Hugo Alfonso Muñoz Quesada, La Asamblea Legislativa en Costa Rica (San Jose, 1977) and Magda Ines Rojas, El Poder Ejecutivo en Costa Rica (San José, 1980).

45. This pivotal institution has remained little studied. Existing essays are: Mauro Murillo,

' El Tribunal Supremo de Elecciones', in Carlos José Gutierrez (ed.), Derecho constitucional costarricense (San José, 1983) and Rafael Villegas Antillón, ' El Tribunal Supremo de Elecciones y el Registro Civil de Costa Rica', Cuadernos de CAPEL, No. 18 (San Jose, 1987). 


\section{Conclusions}

Costa Rica's long-term standing as one of the few countries in Latin America with a stable democracy has prompted many observers to view its polity as a natural expression of a racially homogeneous and relatively egalitarian society. Though the absence of severe social and economic cleavages has helped to reduce the intensity of conflict in Costa Rican society, it remains unclear whether underlying social and economic consensus is responsible for the democratisation of this country's political system. Comparative analysis, for example, reveals that democratic regimes can emerge in societies - like Chile's - characterised by a highly unequal distribution of land and other resources and wracked by class conflict.

Even if not confronted with troublesome counter-evidence, however, standard sociological approaches do not explain why incumbents and opposition movements have both respected and violated democratic practices in Costa Rica. Until the late nineteenth century, public officials came to power through force of arms or were selected in fraudulent, often hastily organised elections. It has only been since the turn of the century that politicians gradually began to eschew the use of force and to compete within the electoral arena for control of the state. The use of violence and fraud to capture state power only declined in the aftermath of the 1948 civil war.

This article argues that the structure of the political system created by the 1871 constitution was responsible for the instability that afflicted Costa Rican politics before the mid-twentieth century. The overwhelming importance of the presidency encouraged incumbents to retain state power and, as a result, left the opposition with few options but rebellion to affect the course of public policy. This cycle was broken in Costa Rica as incumbents, under the threat of being overthrown, desisted from retaining power or from imposing their successors on the presidency. Political competition also became more peaceful as those parties that failed to capture the presidency were nevertheless compensated by being allowed to occupy legislative offices. Compliance with the results of the ballot box was therefore a product of a set of decisions, made in an environment of chronic instability, to share control of the state.

Another key finding of this analysis is that a democratic regime became consolidated in Costa Rica only once the institutional preponderance of the presidency was curtailed. Despite the strategic bargains struck between incumbents and their opponents, the threat of instability persisted until well into the twentieth century. Until the constitutional reforms of 1910, presidents bypassed Congress by convening the Permanent Commission 
to enact legislation, especially to declare states of siege during electoral campaigns. Until the late 1940s, presidents manipulated the electoral arena for partisan advantage by appointing the officials responsible for the preparation of the registry of voters, for the organisation of polling stations and for the tally of the vote.

The reform of Costa Rican presidentialism was, in part, a result of the decision made by incumbents seeking to defuse the threat posed by armed sectors of the opposition. Institutional changes also were a product of coalitions formed by pro-reform presidents and make-shift legislative majorities. Attempting to secure the survival of electoral institutions and their ability to triumph in fraud-free electoral contests, reformist incumbents and their legislative allies enacted constitutional and other institutional changes that damaged the ability of parties and/or locally based political machines to manipulate electoral laws for partisan advantage. Severe threats to political instability, along with a propitious balance of legislative power, thus permitted pro-reform politicans to reduce the powers held by the executive branch of government.

What my analysis of the Costa Rican case also demonstrates is that the common practice of endowing chief executives with extraordinary powers has aggravated - if not created - conflict in the countries of Latin America. The power to declare states of siege unilaterally, or with minimal legislative consultation, for example, has permitted incumbents to use the powers of their office to crush their opponents. ${ }^{46}$ Their custody of the electoral machinery of the state also has furnished them with another powerful weapon. As my analysis of the Costa Rican case demonstrates, the temptations created by such arrangements proved to be too great for most incumbents to ignore.

Until their presidential systems were reformed, Argentine, Chilean and Uruguayan politics also remained unstable. The power held by Argentine presidents to dismiss popularly elected governors, for example, is credited with aggravating the conflicts between government and opposition that led to the collapse of democracy in 1930.47 Civil wars and other types of conflict in Chile, for example, were often provoked by

46 Fine studies of these problems are Brian Loveman, The Constitution of Tyranny: Regimes of Exception in Spanish America (Pittsburgh, 1994) and Diego Valades, La dictadura constitucional en América Latina (Mexico, D.F., 1974).

47. Ann Louise Potter, ' The Failure of Democracy in Argentina, 1916-193o: An Institutional Perspective', Journal of Latin American Studies, vol. 13, no. i (1981) and Natalio R. Botana, El orden conservador : la politica argentina entre 1880-1916 (Buenos Aires, 1979). Also, see N. Guillermo Molinelli, Presidentes y congresos en Argentina (Buenos Aires, 1991). 
presidents who abused the powers of their office. ${ }^{48} \mathrm{~A}$ democratic regime became consolidated in Uruguay as incumbents shared power with their opponents and created an autonomous system of electoral courts in 1925.49

Underscoring the importance of institutional arrangements in shaping political behaviour does not deny the role played by social and economic conflicts in fomenting regime breakdowns. The absence of severe social cleavages in Costa Rican politics undoubtedly decreased the intensity of conflict over control of the state. Strife about the place of the Church in Chilean society, along with the emergence of urban labour unions and agrarian movements, only exacerbated the conflicts created by the struggle to retain or to gain control of the executive branch of government in Chile. ${ }^{50}$ What these studies and this article, however, indicate is that prevailing accounts emphasising the impact of economic underdevelopment and class cleavages on the development of democratic regimes need to be re-examined and perhaps even substantially modified. ${ }^{51}$

48 Julio Heise González, El periodo parlamentario, 1861-192f: democracia y gobierno representativo en el período parlamentario (Santiago, 198z) and J. Samuel Valenzuela, Democratización via reforma: la expansión del sufragio en Chile (Buenos Aires, 1985).

49 Rolando Franco, Democracia 'a la uruguaya' : análisis electoral, 1927-198, (Montevideo, 1984); Hector Gros Espiell, La Corte Electoral del Uruguay (San José, 1990); Philip Taylor, Government and Politics of Uruguay (New Orleans, 1960).

50 An analysis of the impact of these cleavages on Chilean politics is Timothy R. Scully, Rethinking the Center: Party Politics in Nineteenth and Twentieth Century Chile (Stanford, 1992). An analysis of Chilean presidentialism is Arturo Valenzuela, 'Political Parties and the Failure of Presidentialism in Chile: A Proposal for a Parliamentary Form of Government', in Juan J. Linz and Arturo Valenzuela (eds.), The Failure of Presidential Democracy.

51 The most prominent sociological study is : Dietrich Rueschemeyer, Evelyne Huber Stephens and John D. Stephens, Capitalist Development and Democracy. Also, see Ruth Berins Collier and David Collier, Shaping the Political Arena: Critical Junctures, the Labor Movement and Regime Dynamics in Latin America (Princeton, 1991). 